\title{
The Effects of Innovation on Firm Performance of Supporting Industries in Hanoi - Vietnam
}

\author{
Nham Tuan ${ }^{1}$ (D), Nguyen Nhan ${ }^{1}$ (D), Pham Giang ${ }^{1}$ (D), Nguyen Ngoc $^{2}$ (i) \\ ${ }^{1}$ University of Economics and Business, Vietnam National University (Vietnam), \\ ${ }^{2}$ Graduate School for International Development and Co-operation, Hiroshima University (Japan) \\ tuannp@,vnu.edu.vn, nhannt55@gmail.com,giangph209@gmail.com,ngocnn22@gmail.com
}

Received:July 2015

Accepted: April 2016

\section{Abstract:}

Purpose: Innovation, including product, process, marketing, and organizational innovation within a firm, is considered as one of essential component for surviving and growing. These innovation activities create value and competitive advantages for successful organizations; therefore, understanding the organization's overall innovation is the first and foremost to understand the role of innovation on firm performance. The objective of this research is to explore two parts: the impacts of innovation on the different aspect of innovation performance, then their effects to firm performance (production, market, and financial performance).

Design/methodology/approach: This study uses primary data from questionnaire survey. The questionnaire involves 4 parts including general information, innovation activities; innovative performance, and firm performance. This research focuses on firms in supporting industries of mechanics, electronics, motorbike and automobile. These firms are in a list of companies (known as The Excellent Vietnamese Companies in Northern and Central Vietnam) established by JETRO and VCCI. There are 150 firms in this list. The questionnaire survey was administered to directors, CEO of those firms during April and May, 2014. Out of the 150 questionnaires sent out, 118 were valid, accounting for $78.7 \%$ of the true response rate. Analysis methodologies of reliability, factor analysis and regression are utilized in this paper. 
Findings: The result demonstrated there are positive effects of process, marketing, and organizational innovations on firm performance in supporting firms. More specifically, the higher the level of innovation activities is, the greater the innovative performance is, which means the larger level of Process, organization and marketing innovation activities are, the higher level of innovative performance are likely to be. Secondly, the higher level of Process, organization and marketing innovative performance, the better level of firm performances is likely to be. To sum up, in order to improve the innovative and firm performance, those firms in supporting industry should highly concentrate on process, marketing, and organizational innovation activities, rather than product innovation activities.

Originality/value: Initially, this study applies successfully the model which supposing innovation is a process, then clarifying innovation definition through the impact of innovation activities on innovative performances. Secondly, this research confirmed the positive impact of innovative performances on firm performances. It provided one more empirical evidence of the relationship between innovation and firm performance. For practitioners, organizational innovation and process innovation are more important factors affecting innovative performance and firm performance than product and marketing innovation. Therefore, enterprises should focus and mobilize resources to create improvement in organizational structure and manufacturing processes.

Keywords: innovation, manufacturing firm, innovative performance, firm performance

\section{Introduction}

Currently, one of the major challenges that the world economy faces is the decline in labor productivity growth, which has a negative impact on economic growth period after the global financial crisis for 2008. Efforts of countries in the world to deal with these issues so far seem to be temporary; hence it would not solve the problems thoroughly.

Although Vietnam's economic growth has been quite high since the Doi Moi policy (renovation) in 1986, a slowdown of the growth in recent years has been due to the decline of labor productivity growth. In addition, Vietnam has been facing serious challenges such as climate change, environmental protection, resource conservation... In order to solve these problems in long term; Vietnam as well as other economies needs to set focus on the root problems, especially innovation. 
In the Vietnamese economy, a large sector contributed to the economic development is the enterprises. Since the Doi Moi in 1986, an increasing number of both Vietnamese and FDI enterprises have invested in Vietnam. They have played an important role for economic growth and employment creation. One of the most important ways through which businesses can contribute to productivity and economic growth is their ability to innovation. A comprehensive review, innovation always is essential for the survival of particular businesses and organizations in general. In fact, innovation still occurs in Vietnamese enterprises when there are external assistance programs for them and their own internal efforts to promote innovation. However, they still need to make more efforts in terms of innovation to survive and grow in the fiercely competitive environment. Among these efforts, researches focusing on innovation are one essential method to establish knowledge of innovation in a systematic way, which guides the decisions of managers and governments practically and professionally.

In recent years, in the world there have been a plenty of researches about innovation on companies, but it is very little in Vietnam, especially testing the effects of innovation on firm performance. Therefore, this study will focus on researching impacts of innovation on firm performance in supporting industry of mechanics, electronics, motorbike and automobile in Hanoi.

\section{Literature Review}

\subsection{Innovation}

Literature of innovation shows that any firm needs innovation to succeed and survive (Jimenez \& Sanz-Valle, 2011; Bell, 2005; Cho \& Pucik, 2005; Gopalakrishnan \& Damanpour, 1997; Damanpour, 1996; Fiol, 1996; Wolfe, 1994) and gain sustainable competitive advantage (Standing \& Kiniti, 2011; Bartel \& Garud, 2009; Johannessen, 2008; Mumford \& Licuanan, 2004). The fact remains that there are a large number of definitions of innovation in the literature, however, exact definition of the term was described globally (Amara \& Landry, 2005). In its broadest sense, the term comes from the Latin - innovare - meaning 'to make something new'. UK Department of Trade and Industry (2007) assumes that innovation is a process of turning opportunity into new ideas and of putting these into widely used practice. Furthermore, innovation was firstly described by the German economist and political scientist - Schumpeter (1934) defined it as "the driving force for development". Five manifestations of innovation were proposed in his definition (Vyas, 2009):

- Creation of new products or qualitative improvements in existing products

- Use of a new industrial process

- New market openings 
- Development of new raw-material sources or other new inputs

- New forms of industrial organizations

In this research, (OECD, 2005), which is the primary global basis of guidelines for defining and assessing innovation activities, has been taken as the fundamental reference source to describe, identify and classify innovations at firm level. In the third edition of the Oslo Manual, innovation is defined as the “implementation of a new or significantly improved product (goods or service), process, a new marketing technique or a new organizational method in business practices, workplace organization or external relations", (OECD \& Eurostat, 2005). OECD, (2005) also classified innovation into four different types which are product innovation, process innovation, marketing innovation and organizational innovation.

\subsection{Innovative and Firm Performance}

Murphy, Trailer and Hill (1996) claimed that firm performance is a multidimensional concept, and three indicators can be production, finance or marketing (Sohn, Joo \& Han, 2007), or consequences such as growth and profit (Wolff \& Pett, 2006). It can be measured with objective or subjective indicators (Dawes, 1999; Harris, 2001). In this study, performance involves 4 indicators: production, market, and financial performance.

Innovative performance is the combination of overall organizational achievements as a result of renewal and improvement efforts done considering various aspects of firm innovativeness, for instance, processes, products, marketing, organizational structure, etc. Therefore, innovative performance is a composite construct, (Hagedoorn \& Cloodt, 2003) based on various performance indicators pertaining, such as, to the new patents, new product announcements, new projects, new processes, and new organizational arrangement.

\subsection{Supporting Industries in Vietnam}

Supporting industries' definition differs in different contexts. In the broadest sense, it is defined as a group of producers of manufactured inputs. Supporting industries produce inputs in order to complete final good, more specifically intermediate and capital goods (Mori, 2005). In a narrower sense, supporting industries are customized as a specific industry or group of industries, e.g. supporting industries of the leather footwear industry produce parts of footwear, processed leather, leather working machinery, and design services. Supporting industries of the assembling industries, such as motorcycle, automobiles, and 
electronics, supply material inputs and their processing, production parts as well as machinery and tooling to produce these parts, and services (Ratana, 1999; Thuy, 2006).

Thuy (2006) clarifies four common concepts of supporting industries and their respective scopes. The core concept, the smallest scope, defines supporting industries as industries that supply parts, components and tools to produce parts and components. Broad Scope 1 defines supporting industries as those that supply parts, components, and tools to produce parts and components, and production services such as logistics, storing, distribution and insurance. Broad Scope 2 considers supporting industries as those that supply all physical inputs including parts, components, tools, machines and materials. Broadest Scope 3, consisting of both Broad Scopes 1 and 2, is the broadest scope of supporting industries. Noticeably, the scopes of supporting industries do not specify firm size or ownership and can include foreign and local firms, larger firms and SMEs.

In Vietnam's case, the term supporting industries official used in Vietnam appeared relatively late in 2003 (Thuy, 2006). As suggested by Thuy (2006) and specified in Vietnam's Master Plan for Development of Supporting Industries (Tuat, 2007), the core concept is more suitable to mobilize all resources for the development of supporting industries due to budget constraints, underdeveloped industrial bases, and pressures of international integration and competition. An operational definition of supporting industries appropriate to the purposes of this research and policymaking in Vietnam is: Supporting industries can be defined as a group of industrial activities which supply intermediate inputs (i.e., parts, components) and part of capital goods (tools to produce these parts and components) for assembly-type or processing industries.

It has been said that supporting industries are extremely primitive in Vietnam. However, a survey by Ichikawa (2005) indicated that it is more appropriate to say that Vietnam's supporting industries are finally burgeoning and beginning to develop. At present, there are at least two large-scale industries that may become pivotal ones to promote the development of other supporting industries. They are the motorcycle and electronics industries with localization rates of $70-80 \%$ in number of parts, but much less in value. To sum up, this study focuses on firms in supporting industries of mechanics, electronics, motorbike and automobile. The conceptual framework for impact of innovation on innovative and firm performance (see Figure 1).

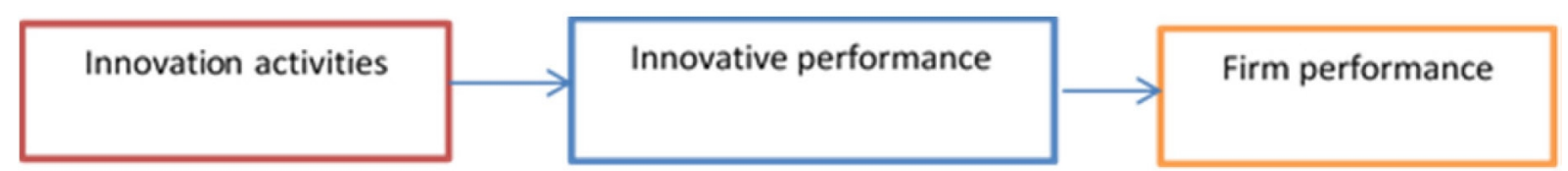

Figure 1. The conceptual framework of innovation and firm performance (authors) 
Innovation can be measured as a result or a process, the former means innovation results from other activities and its results effect positively on firm performance (financial, market, and production performance), the latter considers that innovation is measured by the process from innovation activities to innovative performance. This study considers innovation as a process described in Figure 2.

\subsection{Hypothesis Development}

The global competition, which became particularly tough after 80 's, forced the companies focusing on their business strategies, especially on innovations (Kuratko \& Hodgetts, 2001). At the present time, due to the tough global competition, both individuals and companies begin to evaluate and to apply their innovation strategies and entrepreneurial abilities with the purpose of gaining competitive advantage (Drucker, 1985; Hult \& Ketchen Jr., 2001).

Actually, the key reason for innovativeness is the desire of firms to obtain increased business performance and increased competitive edge. Companies procure additional competitive advantage and market share according to the level of importance they give to innovations, which are vital factors for companies to build a reputation in the marketplace and thus to increase their market share. Metcalfe, (1998) stated that when the flow of newness and innovations desiccates, firms' economic structure settles down in an inactive state with little growth. Therefore, innovation plays a significant role in creating the differences of performance and competition among firms, regions and even countries. For instance, the study by Fagerberg, Mowery and Nelson (2004) revealed that innovative countries had higher productivity and income than the less-innovative ones. OECD reports pointed out that companies that developed innovations in a more decisive way and rapidly, had also more qualified workers, paid higher salaries and provided more conclusive future plans for their employees. In fact, the effects of innovations on firm performance differ in a wide spectrum from sales, market share and profitability to productivity and efficiency (OECD, 2005).

The traditional explanation for the positive relationship between firm level innovation and firm performance rests on Schumpeter's work (1934). He argued that innovative new products when first introduced to the market face limited direct competition and, as a result, allow firms to enjoy relatively high profits. Over time, these high profits are likely to erode due to imitation and competition, but firms that continue introducing innovative new products may be able to achieve high profitability for a sustained period (Sharma \& Lacey, 2004). Like many other scholars, Varis \& Littunen, (2010) argued that the ultimate reason for firms to engage in innovation activities is to improve firm performance and success. The impact of innovation activities on firm performance are also emphasized in Oslo Manual (OECD \& Eurostat, 2005). There are few studies in the literature on the relationship between innovation 
and firm performance. The number of studies based on the classification of innovation according to the Oslo Manual (OECD \& Eurostat, 2005) is even fewer. This study aimed to fill this gap in the literature by testing this relationship in supporting industry.

From all theoretical foundation above, we assume a positive relationship between innovation and firm performance in supporting industries. And to specify the conceptual framework more clearly, Figure 2 show the analytical framework of this study which is the detail model of relationship between innovation and firm performance. The analytical framework consists of 2 branches with 4 hypotheses:

Branch 1: The relationship between innovation activities and innovative performance

Branch 2: The relationship between innovative performance and firm performance

Hypothesis H1: The bigher the level of innovation activities is, the greater the innovative performance is.

Hypothesis H2: The greater the innovative performance is, the greater the production performance is

Hypothesis H3: The higher the level of innovative performance is, the greater of the market performance improvement is.

Hypothesis H4: The higher the level of innovative performance is, the greater of the finance performance improvement is.

\section{Branch 1}

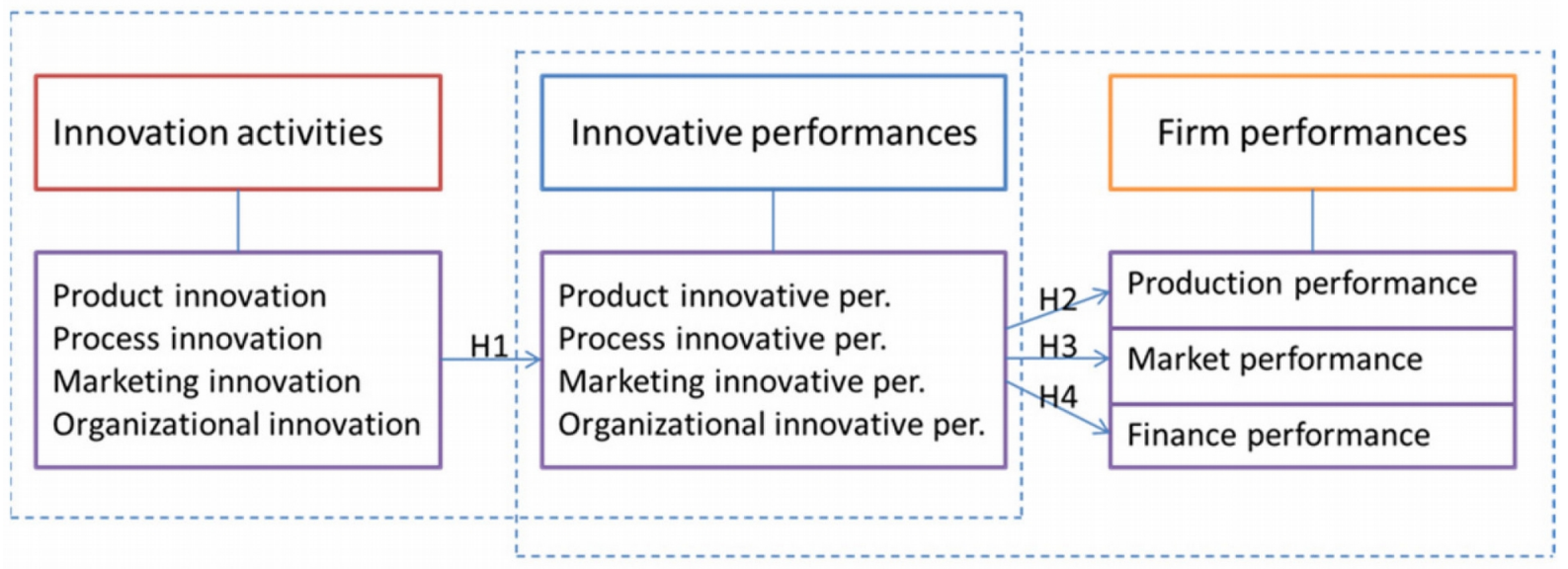

Branch 2

Figure 2. Hypothesis development of the effects of innovation on firm performance (authors) 


\section{Research Methodology}

\subsection{Data and Sample}

This study uses primary data from questionnaire survey. The questionnaire based on Gunday, Ulusoy, Kilic and Alpkan (2011) involves 4 parts including general information, innovation activities; innovative performance and firm performance. Innovation activities include product innovation (5 items), process innovation (3 items), organizational innovation (9 items), and marketing innovation (5 items). Innovative performance consists of product innovative performance (3 items) and 1 item for each of process, organizational and marketing innovative performance. Firm performance includes production performance (4 items), marketing performance (3 items), and finance performance (4 items). These indicators are asked for over past three years and measured by 5 point Likert scale ranging from: $1=$ strongly disagree, $2=$ disagree, $3=$ neutral, $4=$ agree, $5=$ strongly agree.

This research focuses on firms in supporting industries of mechanics, electronics, motorbike and automobile. These firms are in a list of companies (known as The Excellent Vietnamese Companies in Northern and Central Vietnam) established by JETRO and VCCI. There are 150 firms in this list. The questionnaire survey was administered to directors, CEO of those firms during April and May, 2014. It was followed by telephone calls to remind participation and return of questionnaires. Prior to the launch of the official questionnaires, a pilot test of the questionnaire was administered to five firms and experts of the fields of this research. Some modifications were made in several question constructs related to the layout of the questionnaire and some theoretical ambiguities. Out of the 150 questionnaires sent out, 131 were returned. Among the 131, 118 were valid, accounting for $78.7 \%$ of the true response rate.

\subsection{Analysis Methodology}

\subsubsection{Reliability Analysis}

Cronbach's alpha is a common measure of internal consistency (reliability) of a test or scale. Internal consistency describes the extent to which all the items in a test measure the same concept or construct and hence it is connected to the inner-relatedness of the items within the test (Tavakol \& Dennick, 2011). According to (George \& Mallery, 2003), an acceptable reliability score should be 0.7 or higher. Nevertheless, lower thresholds are sometimes used in the literature (Reynaldo \& Santos., 1999). In this research, scales which have Cronbach's alpha coefficient greater than or equal to 0.7 will be accepted. 


\subsubsection{Exploratory Factor Analysis}

Exploratory factor analysis is a statistical technique which is used for data reduction and summarization. The primary objectives of an exploratory factor analysis are to determine (1) the number of common factors influencing a set of measures; (2) the strength of the relationship between each factor and each observed measure states Decoster (1998).

Initially, it is necessary to test the sampling adequacy of factor analysis based on Kaiser-Meyer-Olkin (KMO) Measure. In case of KMO has value between 0.5 and 1.0 and Sig. is smaller than 0.5, factor analysis is more appropriate. In case of $\mathrm{KMO}$ has value smaller than 0.5 or Sig. is greater than 0.5 , it indicates that factor analysis may not be appropriate.

\subsubsection{Regression Analysis}

Regression analysis is a modeling technique for analyzing the relationship between a real-valued dependent variable $\mathrm{Y}$ and one or more independent variables X1, X2, X3,..., Xk (Ragsdale, 2007). The goal in regression analysis is to identify a function that describes the relationship between these variables therefore assessing the impact of each independent variable on dependent variable as well as predicting the change in dependent variable when there is any change in independent variables.

\section{Analysis Results and Discussions}

\subsection{Reliability Analysis}

After reliability analysis, the Cronbach's Alpha coefficients of four dimensions of Innovation Activities (Product Innovation, Process Innovation, Organizational Innovation, and Marketing Innovation) and 3 types of Firm Performances (Production Performance, Marketing Performance, and Finance Performance) are followed by Table 1 through Reliability analysis, all scales are accepted (which are higher than 0.7$)$. Therefore, they are continued forward the exploratory factor analysis. 


\begin{tabular}{|l|r|}
\hline Scale & Cronbach's Alpha \\
\hline Product Innovation & 0.901 \\
\hline Process Innovation & 0.832 \\
\hline Organizational Innovation & 0.941 \\
\hline Marketing Innovation & 0.926 \\
\hline Product innovative performance & 0.767 \\
\hline Production Performance & 0.832 \\
\hline Marketing Performance & 0.719 \\
\hline Finance Performance & 0.926 \\
\hline
\end{tabular}

Table 1. Reliability analysis results

\subsection{Exploratory factor analysis}

KMO value of innovation activities and 3 factors of firm performances (production performances, market performances and finance performances) are higher than 0.05 with Sig. of 0.00 . Therefore, the validity of data for exploratory factor analysis is confirmed. For innovation activities, those scales comprises of 22 variables. After making reliability analysis, no item of each scale is not reliable to be rejected. Exploratory factor analysis is conducted with these 22 variables to measure convergence of variables along with components, extracted into 4 components, namely PRODUCT; PROCESS; ORGANIZATION; and MARKETING. 


\begin{tabular}{|c|c|c|c|c|}
\hline & Rotatc & onent Matr & & \\
\hline & & Comp & & \\
\hline & 1 & 2 & 3 & 4 \\
\hline ORGANIZATION9 & .897 & & & \\
\hline ORGANIZATION8 & .889 & & & \\
\hline ORGANIZATION5 & .849 & & & \\
\hline ORGANIZATION6 & .808 & & & \\
\hline ORGANIZATION4 & .744 & & & \\
\hline ORGANIZATION1 & .734 & & & \\
\hline ORGANIZATION7 & .691 & & & \\
\hline ORGANIZATION3 & .686 & & & \\
\hline ORGANIZATION2 & .625 & & & \\
\hline MARKETING4 & & .937 & & \\
\hline MARKETING1 & & .906 & & \\
\hline MARKETING5 & & .889 & & \\
\hline MARKETING3 & & .846 & & \\
\hline MARKETING2 & & .751 & & \\
\hline PRODUCT5 & & & .913 & \\
\hline PRODUCT2 & & & .892 & \\
\hline PRODUCT1 & & & .815 & \\
\hline PRODUCT4 & & & .738 & \\
\hline PRODUCT3 & & & 637 & \\
\hline PROCESS3 & & & & .861 \\
\hline PROCESS1 & & & & .823 \\
\hline PROCESS2 & & & & .752 \\
\hline Cumulative\% & $38.40 \%$ & $56.11 \%$ & $67.45 \%$ & $75.15 \%$ \\
\hline
\end{tabular}

Extraction Method: Principal Component Analysis.

Rotation Method: Varimax with Kaiser Normalization.

a. Rotation converged in 4 iterations.

Table 2. Exploratory factor analysis for innovation activities

For firm performance, Production performances includes 4 observed variables, extracted to 1 component

- PRODUCTION_PER; Market performances includes 3 observed variables, extracted to 1 component

- MARKET_PER; Finance performances includes 4 observed variables, extracted to 1 component

- FINANCE_PER. 


\begin{tabular}{|l|r|}
\hline \multicolumn{2}{|c|}{ Component Matrix $^{\text {a }}$} \\
\cline { 2 - 2 } & Component \\
\hline PRODUCT_PER4 & .945 \\
\hline PRODUCT_PER3 & .929 \\
\hline PRODUCT_PER1 & .853 \\
\hline PRODUCT_PER2 & .524 \\
\hline Cumulative\% & $68.92 \%$ \\
\hline
\end{tabular}

Extraction Method: Principal

Component Analysis.

a. 1 component extracted

\begin{tabular}{|l|r|}
\hline \multicolumn{2}{|c|}{ Component $^{-}$Matrix $^{\mathrm{a}}$} \\
\hline & Component $^{-1}$ \\
\hline MARKET_PER2 & .921 \\
\hline MARKET_PER3 & .804 \\
\hline MARKET_PER1 & .703 \\
\hline Cumulative\% & $66.29 \%$ \\
\hline
\end{tabular}

Extraction Method: Principal

Component Analysis.

a. 1 component extracted

\begin{tabular}{|l|r|}
\hline \multicolumn{2}{|c|}{ Component Matrix $^{\text {a }}$} \\
\hline \multirow{2}{*}{} & Component \\
\cline { 2 - 2 } & 1 \\
\hline FINANCE_PER3 & .901 \\
\hline FINANCE_PER1 & .837 \\
\hline FINANCE_PER2 & .836 \\
\hline FINANCE_PER4 & .807 \\
\hline Cumulative\% & $71.562 \%$ \\
\hline
\end{tabular}

Extraction Method: Principal

Component Analysis.

a. 1 component extracted

Table 3. Component Matrix of Firm performance

\subsection{Regression Analysis}

The analytical framework consists of two branches which model 1 considers the impact of innovation activities on innovative performances and model 2 relates to the effect of innovative performance on firm performances. In the model 1, innovative performance is an aggregate dependent variable while it will be divided into four detailed innovative performance (product, process, marketing, and organizational). The reason is that relationship between innovation and firm performance is main purpose of this paper.

For the first model (H1), four dimensions of innovation activities - including Product Innovation, Process Innovation, Organizational Innovation, and Marketing Innovation- considered as independent variables while Innovative performances is an aggregate dependent variable.

After regression analysis, the innovation activities explain $46.7 \%$ of the variance in innovative performances, and there is the positive impact of the independence variables on the dependent variables. More specifically, three of four dimensions of innovation activities (Process, Organizational, and Marketing Innovation) have the impact statistically on innovative performance which Organizational Innovation contributes the greatest proportion then Process Innovation and Marketing Innovation at the second and third proportion rate, respectively. Product Innovation has no statistical influence on innovative performance. 


\begin{tabular}{|c|c|c|}
\hline Independent variables: & Beta & Sig. \\
\hline PRODUCT & -0.054 & 0.197 \\
\hline PROCESS & 0.181 & 0.000 \\
\hline MARKETING & 0.086 & 0.034 \\
\hline ORGANIZATION & 0.250 & 0.000 \\
\hline R2 & \multicolumn{2}{|c|}{0.485} \\
\hline Adjusted R2 & \multicolumn{2}{|c|}{0.467} \\
\hline $\mathrm{F}$ & \multicolumn{2}{|c|}{26.636} \\
\hline
\end{tabular}

Table 4. Regression analysis results for branch 1

For three models of branch 2 ( $\mathrm{H} 2, \mathrm{H} 3, \mathrm{H} 4)$, four dimensions of innovative performances - including Product innovative Performance, Process innovative Performance, Marketing innovative Performance, and Organizational innovative Performance- are considered as independent variables for these three models while production, market and finance performances are dependent variables of model H2, H3, $\mathrm{H} 4$, respectively.

\begin{tabular}{|l|r|r|r|r|r|r|}
\hline & \multicolumn{2}{|c|}{ Model H2 } & \multicolumn{2}{c|}{ Model H3 } & \multicolumn{2}{c|}{ Model H4 } \\
\hline Independent variables: & \multicolumn{1}{|c|}{ Beta } & \multicolumn{1}{c|}{ Sig. } & \multicolumn{1}{c|}{ Beta } & \multicolumn{1}{c|}{ Sig. } & \multicolumn{1}{c|}{ Beta } & \multicolumn{1}{c|}{ Sig. } \\
\hline PRODUCT_PER & -0.012 & 0.876 & 0.075 & 0.326 & -0.031 & 0.708 \\
\hline PROCESS_PER & 0.305 & 0.000 & 0.295 & 0.000 & 0.292 & 0.001 \\
\hline MARKETING_PER & 0.269 & 0.001 & 0.236 & 0.003 & 0.243 & 0.005 \\
\hline ORGANIZATION_PER & 0.282 & 0.001 & 0.341 & 0.000 & 0.266 & 0.002 \\
\hline R2 & \multicolumn{2}{|c|}{0.359} & & 0.400 & & 0.313 \\
\hline Adjusted R2 & \multicolumn{2}{|c|}{0.337} & & 0.379 & & 0.289 \\
\hline F & \multicolumn{2}{|c|}{15.855} & 18.814 & \multicolumn{2}{|c|}{12.872} \\
\hline
\end{tabular}

Table 5. Regression analysis results for branch 2

After regression analysis, the innovative performances plain $33.7 \%$ of production performances, $37.9 \%$ of market performances, and $28.9 \%$ of finance performances. More specifically, Process innovative Performance, Marketing innovative Performance, and Organizational innovative Performance have the statistical significant impact on those 3 models while Product innovative Performance proves no influence statistically on three types of firm performances in all models.

For model $\mathrm{H} 2$ and H4, Process innovative Performance have the greatest impact on Production Performance and Market Performance while Organizational Performance and Marketing Performance place the second and third important roles, respectively. To turn to model H3, Organizational 
Performance becomes the most important factor which affects Finance Performance while Process Performance and Marketing Performance come second and third vital factors, respectively.

In conclusion, for branch 1, the hypothesis $\mathrm{H} 1$ related to the impact of innovation activities on innovative performance, is partly supported by Process, Organization and Marketing innovation, while Product Innovation has no support for innovative performance.

For branch 2, the hypothesis H2, H3, H4 that related to impact of innovative performance on firm performance (Production Performance, Market Performance, and Finance Performance) are partly supported by Process innovative Performance, Marketing innovative Performance and Organizational innovative Performance, while Product innovative Performance has no support for any firm performance. Findings from those analysis results show that firms mostly focus on process, organizational and marketing innovation activities rather than product innovation ones. This is true in firms of supporting industry in Vietnam when they just received orders of specific products from assemblers who already designed models of products. In that case, firms in supporting industry do not have chance to innovate the models. Therefore, they tried to make something new in process, organizational and marketing activities. Moreover, in terms of level of impact among process, organizational and marketing innovation, it can be seen that marketing innovation activities are at least impact level on performance. It reflects a fact that firms in supporting industry may have long term relationship with assemblers. In other words, assemblers usually work with a limited number of suppliers. In that sense, firms in supporting industry seem not to focus on the marketing innovation activities.

\section{Conclusions and Implications}

This study focuses on the impacts of innovation activities on the different aspect of innovation performance and in its turn, their effects to firm performance of 118 firms in supporting industry in Vietnam. After data analyses through quantitative methodologies of reliability, exploratory factor analysis and regression analysis, the result of this study illustrates that:

Firstly, process, organization and marketing innovation respectively have the significantly positive impact on innovative performances. More specifically, the higher the level of innovation activities is, the greater the innovative performance is, which means the larger level of Process, organization and marketing innovation activities are, the higher level of innovative performance are likely to be. Meanwhile, product innovation activities have no statistical impact on the innovative performance.

Secondly, process, organization and marketing innovative performances have the positive influence on production, market and finance performances. To be specific, the higher level of Process, organization 
and marketing innovative performance, the better level of firm performances is likely to be. Once again, product innovative performance has no impact on any type of firm performance.

To sum up, in order to improve the innovative and firm performance, those firms in supporting industry should highly concentrate on process, marketing, and organizational innovation activities, rather than product innovation activities. These findings provide three following implications for academics and practitioners, and policy makers.

For academics:

Initially, this study applies successfully the model which supposing innovation is a process, then clarifying innovation definition through the impact of innovation activities on innovative performances. Secondly, this research confirmed the positive impact of innovative performances on firm performances. It provided one more empirical evidence of the relationship between innovation and firm performance.

\section{For practitioners:}

Organizational innovation and process innovation are more important factors affecting innovative performance and firm performance than product and marketing innovation. Therefore, enterprises should focus and mobilize resources to create improvement in organizational structure and manufacturing processes.

Enterprises should update information on technology changes in the advanced countries, especially countries with high technology background related to supporting industries; seeking opportunities for long term cooperation with foreign enterprises and domestic ones in the same industry.

Because innovative performances are strongly impacted from organizational innovation and process innovation activities, companies should focus on enhancing organizational innovation and process innovation. Enterprises should also create a creative environment inside themselves to encourage innovation through programs, awarding feasible creativities. 


\section{Limitations and Suggestions for Future Research}

Innovation is an undeniable issue for future development of each company, industry, and region, however in Vietnam, there were a limit number of researches related to innovation activities, innovative performances, and firm performances. To broaden the topic, other researches should be encouraged to develop some topics about the external and internal factors of organization impacting on innovation activities or the effect of innovation activities on firm performances. Moreover, the next research should be conducted in large scale such as industries or regions with various types of corporations.

\section{References}

Amara, N., \& Landry, R. (2005). Sources of information as determinants of novelty of innovation in manufacturing firms: Evidence from the 1999 statistics Canada innovation survey. Technovation, 25(3), 245-259.http://dx.doi.org/10.1016/S0166-4972(03)00113-5

Bartel, C., \& Garud, R. (2009). The role of narratives in sustaining organizational innovation. Organization Science, 20(1), 107-117. http://dx.doi.org/10.1287/orsc.1080.0372

Bell, G. (2005). Clusters, networks, and firm innovativeness. Strategic Management Journal, 26(3), 287-295. http://dx.doi.org/10.1002/smj.448

Cho, H., \& Pucik, V. (2005). Relationship between innovativeness, quality, growth, profitability, and market value. Strategic Management Journal, 26(6), 555-570. http://dx.doi.org/10.1002/smj.461

Damanpour, F. (1996). Organizational complexity and innovation: developing and testing multiple contingency models. Management Science, 42(5), 693-716. http://dx.doi.org/10.1287/mnsc.42.5.693

Dawes, J. (1999). The relationship between subjective and objective company performance measures in market orientation research: further empirical evidence. Marketing Bulletin-Department of Marketing Massey University, 10, 65-75.

Decoster, J. (1998). Overview of factor analysis. Online. Available at: http://www.stat-help.com/ (Accessed: April 2012).

Drucker, P. (1985). Innovation and Entrepreneurship: Practice \& Principles. New York: Harper \& Row.

Fagerberg, J. Mowery, D.C., \& Nelson, R. (2004). The Oxfort Handbook of Innovation, Oxford: Oxford University Press. 
Fiol, C. (1996). Squeezing Harder doesn't always work: continuing the search for consistency in innovation research. Academy of Management Review, 21(4), 1012-1021.

http://dx.doi.org/10.5465/AMR.1996.15868543

George, D., \& Mallery, P. (2003). SPSS for Windows step by step: A simple guide and reference 11.0 update. 4th ed. Boston: Allyn \& Bacon.

Gopalakrishnan, S., \& Damanpour, F. (1997). A Review of innovation research in economics, sociology, and technology management. Omega, 25(1), 15-28. http://dx.doi.org/10.1016/S0305-0483(96)00043-6

Gunday, G., Ulusoy, G., Kilic, K., \& Alpkan, L. (2011). Effects of innovation types on firm performance. International Journal of Production Economics, 133(2), 662-676. http://dx.doi.org/10.1016/j.ijpe.2011.05.014

Hagedoorn, J., \& Cloodt, M. (2003). Measuring innovative performance: Is there an advantage in using multiple indicators? Research Policy, 32(8), 1365-1379. http://dx.doi.org/10.1016/S0048-7333(02)00137-3

Harris, L.C. (2001). Market orientation and performance: Objective and subjective empirical evidence from UK companies. Journal of Management studies, 38(1), 17-43. http://dx.doi.org/10.1111/1467-6486.00226

Hult, G.T.M., \& Ketchen Jr., D.J. (2001). Does market orientation matter? A test of the relationship between positional advantage and performance. Strategic Management Journal, 22(9), 899-906. http://dx.doi.org/10.1002/smj.197

Ichikawa, K. (2005). Improving industrial policy formation. In Ohno, K., \& Thuong, N.V. (Eds.). Building and strengthening supporting industries in Vietnam: A survey report. Hanoi: Publishing House of Political Theory. 235-266.

Jimenez, J.D., \& Sanz-Valle, R. (2011). Innovation, organizational learning and performance. Journal of Business research, 64(4), 408-417. http://dx.doi.org/10.1016/j.jbustes.2010.09.010

Johannessen, J.A. (2008). Organizational innovation as part of knowledge management. International Journal of Information Management, 28(5), 403-412. http://dx.doi.org/10.1016/j.ijinfomgt.2008.04.007

Kuratko, D.F., \& Hodgetts, R.M. (2001). Entrepreneurship: A contemporary approach. Fort Worth: Harcourt College Publishers.

Metcalfe, J.S. (1998). Evolutionary economics and creative destruction. London: Psychology Press. http://dx.doi.org/10.4324/9780203275146

Mori, J. (2005). Development of supporting industries for Vietnam's industrialization: Increasing positive vertical externalities through collaborative training. Master. The Fletcher School, Tufts University, USA. 
Mumford, D.M., \& Licuanan, B. (2004). Leading for innovation: Conclusion, issues, and directions. The leadership quarterly, 15(1), 163-171. http://dx.doi.org/10.1016/j.leaqua.2003.12.010

Murphy, G.B., Trailer, J.W., \& Hill, R.C. (1996). Measuring performance in entrepreneurship research. Journal of Business Venturing, 36(1), 15-23. http://dx.doi.org/10.1016/0148-2963(95)00159-X

OECD (2005). Oslo Manual: Proposed guidelines for collecting and interpreting technological innovation data. 2nd ed. Paris: OECD Publising. http://dx.doi.org/10.1787/9789264013100-en

OECD \& Eurostat (2005). Oslo manual: Guidelines for collecting and interpreting innovation data. 3rd ed. Paris: OECD Publishing.

Ragsdale C.T. (2007). Modeling \& Decision Analysis. Revised edition. Boston: Cengage Learning.

Ratana, E. (1999). Role of small and medium supporting industries in Japan and Thailand. Online. Available at: http://www.ide.go.jp/English/Publish/Download/Apec/pdf/1998 12.pdf (Accessed: January 2010).

Reynaldo, J., \& Santos, A. (1999). Cronbach's alpha: a tool for assessing the reliability scales. Online. Available at: http://www.joe.org/joe/1999april/tt3.php (Accessed: April 2012).

Schumpeter, J.A. (1934). Theory of economic development. Cambridge, MA: Harvard University Press.

Sharma, A., \& Lacey, N. (2004). Linking product development outcomes to market valuation of the firm: The case of the US pharmaceutical industry. Journal of Product Innovation Management, 21(5), 297-308. http://dx.doi.org/10.1111/j.0737-6782.2004.00084.x

Sohn, S.Y., Joo, Y.G., \& Han, H.K. (2007). Structural equation model for the evaluation of national funding on R\&D project of SMEs in consideration with MBNQA criteria. Evaluation and Program Planning, 30(1), 10-20. http://dx.doi.org/10.1016/j.evalprogplan.2006.10.002

Standing, C., \& Kiniti, S. (2011). How can organizations ase wikis for innovation? Technovation, 31(7), 287-295. http://dx.doi.org/10.1016/j.technovation.2011.02.005

Tavakol, M., \& Dennick, R. (2011). Making sense of Cronbach's alpha. International Journal of Medical Education, 2, 53-55. http://dx.doi.org/10.5116/ijme.4dfb.8dfd

Thuy, N.T.X. (2006). Supporting industries: A review of concepts and development. Tokyo, Vietnam Development Forum. 27-50.

Tuat, P.D. (2007). Master plan on the development of supporting industry for Vietnamese industrial sectors until 2010, with a vision to 2020. Hanoi, Industry Policy Strategy Instiute - Ministry of Industry and Trade. 
Varis, M., \& Littunen, H. (2010). Types of innovation, sources of information and performance in entrepreneurial SMEs. European Journal of Innovation Management, 13(2), 128-154. http://dx.doi.org/10.1108/14601061011040221

Vyas, V. (2009). Innovation and New Product Development by SMEs: An Investigation of Scottish Food and Drinks Industry (Doctoral dissertation, Edinburgh Napier University).

Wolfe, R. (1994). Organizational innovation: Review, critique, and suggested research directions. Journal of Management Studies, 31(3), 405-431. http://dx.doi.org/10.1111/j.1467-6486.1994.tb00624.x

Wolff, J.A., \& Pett, T.L. (2006). Small firm performance: Modeling the role of product and process improvements. Journal of Small Business Management, 44(2), 268-284. http://dx.doi.org/10.1111/j.1540627X.2006.00167.x

Journal of Industrial Engineering and Management, 2016 (www.jiem.org)

Article's contents are provided on an Attribution-Non Commercial 3.0 Creative commons license. Readers are allowed to copy, distribute and communicate article's contents, provided the author's and Journal of Industrial Engineering and Management's names are included. It must not be used for commercial purposes. To see the complete license contents, please visit http://creativecommons.org/licenses/by-nc/3.0/. 